\title{
Experience of innovation in the management of a tactical planning system in a higher education institution
}

\section{Experiencia de innovación en la gestión de un sistema de planeación táctica en una dependencia de educación superior}

GONZALEZ-IBARRA, Ana María*†, PALOMARES-RUIZ, María Blanca, TORRES-BUGDUD, Arturo, and TREVIÑO-CUBERO, Arnulfo

Universidad Autónoma de Nuevo León, Facultad de Ingeniería Mecánica y Eléctrica

ID $1^{\text {st }}$ Author: Ana María, Gonzalez-Ibarra / ORC ID: 0000-0002-2117-7476, Researcher ID Thomson: ABH-1316-2021

CVU CONACYT ID: 1174094

ID $1^{\text {st }}$ Co-author: María Blanca, Palomares-Ruiz/ ORC ID: 0000-0002-4079-6969, Researcher ID Thomson: S-4843-2018 CVU CONACYT ID: 339594

ID $2^{\text {nd }}$ Co-author: Arturo, Torres-Bugdud / ORC ID: 0000-0003-2214-9394, Researcher ID Thomson: ABE-2852-2020, ArXiv Author ID: Arturo-Torres-Bugdud, CVU CONACYT ID: 216332

ID $3^{\text {rd }}$ Co-author: Arnulfo, Treviño-Cubero / ORC ID: 0000-0002-0958-8352, CVU CONACYT ID: 373815

\section{Abstract}

This article presents the impact that the redesign of the Tactical Planning System had on a Higher Education department on its users. Using a quantitative methodology and following the cross-sectional descriptive design, a questionnaire was applied to each person in charge in order to obtain their opinion related to the modifications made to the Tactical Planning format, likewise, the user's response to innovation was studied, if they perceive benefits in their management and access to the Planning System. Among the results, the improvement is observed when describing the users who, by doing this redesign, made it easier for them to capture the Planning Exercise

Planning, Strategic, Tactical, System

\begin{abstract}
Resumen
En este artículo se presenta el impacto que tuvo el rediseño del Sistema de Planeación Táctica en una dependencia de Educación Superior en sus usuarios. Haciendo uso de una metodología cuantitativa y siguiendo el diseño descriptivo transversal, se aplicó un cuestionario a cada responsable con el fin de obtener su opinión relacionada con las modificaciones realizadas al formato de Planeación Táctica, así mismo, se estudió la respuesta del usuario a la innovación, si perciben beneficios en su manejo y acceso al Sistema de Planeación. Entre los resultados se observa la mejora al describir los usuarios que, al hacer este rediseño, les facilitó la captura del Ejercicio de Planeación.
\end{abstract}

Planeación, Estratégica, Táctica, Sistema

\footnotetext{
* Author Correspondence (e-mail: mbpalomares@yahoo.com.mx)

$\dagger$ Researcher contributing as first author.
} 


\section{Introduction}

The bases for establishing an institutional development plan in a higher education unit emerge from the objectives and strategies that have been raised in its planning process, which includes the types of planning; the strategic, the tactical and the operational, which are aligned to the mission or reason for being of the institution, being focused towards a vision, considering the actors and interest groups that involve the university community.

For this reason, the innovation experience began with the redesign of a System that was originally created as a tailored suit to meet the needs of the agency, which went through a process of training and sensitization of users, finding Opportunity areas subject to improvement, promoting their modification, all with the purpose of facilitating the exercise of the planning of the academic coordination and the administrative areas that make up the unit, said System was called SPISE (Comprehensive Planning System for Educational Services ) which was submitted for consultation showing the results from the opinions of the users, generating interest in adopting it from other engineering training institutions.

\section{Theoretical Framework}

In the mid-1950s, the term planning was used in some commercial companies which designed formal strategic planning systems which they called Long-Term Planning. At first, its main area was the economic one, however, as time passed, it spread to other sectors, thus being a great influence for the planning management models currently in force (Clímaco Cañarte, J., 2012, p .489).

Planning can be defined as the organization and selection of actions that help to achieve certain objectives, through research and use of available resources (Ramírez et al, 2019, p. 8). As González et al., (2021) cites Cárdenas et al., (2019) Within the field of education, planning and foresight exercises are basic tools that allow tracing the path to the future of education, the Educational institutions are committed to looking for organizational models and elements of direction and planning that lead to an academic-administrative management that promotes the development of innovation projects at all levels of the organization. (p.19)
According to Sheila D. Fournier Bonilla, Karan L. Watson and Cesar Malavé (2000), strategic planning is understood as a tool that aims to generate a series of objectives and goals in order to achieve the mission of a organization. Likewise, for this to be achieved, such planning needs to work.

In addition to the certifications, an educational institution needs to have a Planning that, according to Cruz and Santos (2021), will allow the institution to be directed towards the achievement of its objectives within a specific period of time (p.66). Likewise, it must be based on four fundamental elements that will contribute to the achievement of the vision: Comprehensive training of students, Academic Capacity, Academic Competitiveness and Highperformance Institutional Management (Martínez Corona et al., 2016).

Therefore, in the planning of an engineering training unit, as is the case of the Faculty of Mechanical and Electrical Engineering (FIME) of the Autonomous University of Nuevo León, (UANL) its philosophy is built by the ideals of the institution, established in its principles and values, which are constituted as its reason for being or its base. Likewise, this philosophy is reflected in the vision, which is the image that one seeks to have in a given time; and in its mission that is defined as the reason for being of the institution, that is, its purpose and the scope it has (Chiavenato, I., 2019, pp. 49-55). For this reason, a Planning system is essential to make its mission and vision possible, thereby shaping its development plan.

According to Hernández (2016), tactical planning is carried out by functional areas, it is integrated by a certain organizational unit, be it a department or a specific division, it is developed in the medium term at the intermediate level and emphasizes the activities of the day daily in the various units of the organization in order to obtain satisfactory results. In this sense, according to Ramírez et al. (2019) Tactical Planning took as a reference Strategic Planning. Which are designed for the medium term and their purpose is to plan on issues related to the main departments or areas of the institution. Manages and guarantees the optimization of resources. Unlike Strategic, Tactical planning is directed towards a sector or a product. 
The Tactical Planning of an educational organization must align with accrediting bodies. An accreditation refers to the established statement from a body with professional authority that gives public assurance of the quality of the process or product. To achieve this, PE Planning must be based on the institution's current institutional development program. This planning includes the necessary information to form the Annual Operational Plan (POA) in order to allocate resources according to the needs of each PE (Raygoza et al, 2016, p. 2).

For its part, the Institutional Planning Department of the Veracruzana University (2021) mentions that operational planning includes the integration and execution of projects whose justification, objectives, goals, actions and resources are executed and applied by academic entities and agencies.

It warns that it is linked to the budgeting process, through the allocation of the financial resources necessary for the execution of programs and projects, considering various sources of financing.

The Operational Planning is designed annually, it addresses goals and objectives established in the short term of the activities carried out by each of the departments or areas that make up an institution.

It contains the strategies and resources required to achieve the objectives established in the development plans and which in turn allows the preparation of the Annual Operating Plan (AOP), which is an input for the Results-Based Budget (PBR), which must be aligned with government requirements.

It is through the operational planning exercise that the provisions of tactical planning are monitored annually.

\section{Methodology}

\section{Scope of the investigation}

The application and scope of this research will be carried out in the undergraduate and graduate academic areas that make up the Faculty of Mechanical and Electrical Engineering of the Autonomous University of Nuevo León.

\section{Hypothesis}

The redesign of the Tactical Planning Methodology will contribute to strengthening the Planning culture in the academic administrative areas. This redesign will be focused on the project structure. Likewise, it is intended to align it first with the analysis criteria determined by the frameworks referring to Higher Education, followed by the Guiding Axes and Priority Programs, taking into account the guidelines established by the UANL Finance Commission to finally direct everything towards the requirements of Government Accounting.

\section{Design of the investigation}

To test the hypothesis mentioned above, this research will be carried out through the use of the quantitative research methodology which Hernández - Sampieri and Mendoza Torres (2018) define as a sequential system in order to verify an assumption. It is done through statistical analysis. Its objective is to describe, explain, verify, confirm and predict phenomena in order to generate and test theories (p. 6).

The chosen design is descriptive, crosssectional, which focuses on collecting data only once, in a single time. Its objective is to describe variables in a group of cases, evaluate a specific situation and analyze the incidence of a variable. Likewise, being descriptive, each category of the variable (s) of a specific population is investigated in order to make comparisons between groups or subgroups (Hernández Sampieri and Mendoza Torres, 2018, pp. 176 178).

\section{Sample size quantitative stage}

The total number of Tactical Planning Exercises expected to be received is 30 corresponding to the total number of areas that carry out said Process. Based on this information, the sample size calculation was carried out to carry out the application of the data collection instrument. This procedure was done taking into account a margin of error of $5 \%$ as well as a confidence percentage of $98 \%$, resulting in a sample of 29 participants. 


\section{Data Collection Instrument for the quantitative stage}

For the data collection of this project, an instrument with Likert-type scale questions and open questions was used, which was applied to each of the FIME heads of degree and Academic Coordinators. A questionnaire is understood as a set of questions whose main objective is to measure one or more variables (Hernández Sampieri et al, 2014, p. 217). According to Hernández-Sampieri et al. (2014) the "Likert scaling set of items that are presented in the form of statements to measure the reaction of the subject in three, five or seven categories" $\mathrm{p}$. (238). This instrument is made up of ten questions focused on the impact of the redesign made to the Tactical Planning exercise. The application was through a form created in Microsoft Forms (Figure 2) which was sent through an email invitation. The objective of this instrument is to know the areas of opportunity within the Tactical Planning, which leads to the monitoring of the user experience.

\section{User Experience in capturing Tactical}

\section{Planning}

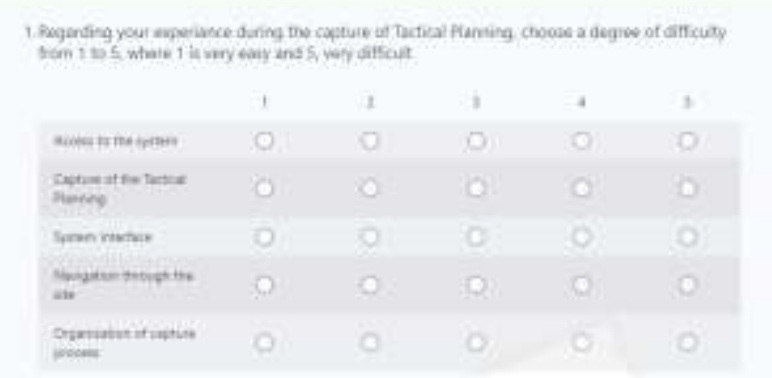

Figure 1 Questionnaire on Tactical Planning Source: Coordination of Strategic Planning FIME, UANL 2021

\section{Results}

The first part of the questionnaire consisted of a short Likert scale where the complexity represented by some aspects of the platform such as access, capture, interface, navigation and organization was asked. The information obtained through the questionnaire shows us that $63 \%$ of the managers surveyed consider that the system is very easy to access, while the remaining $37 \%$ is divided into that accessing the system is of a medium difficulty with a tendency to be simple (Figure 2).

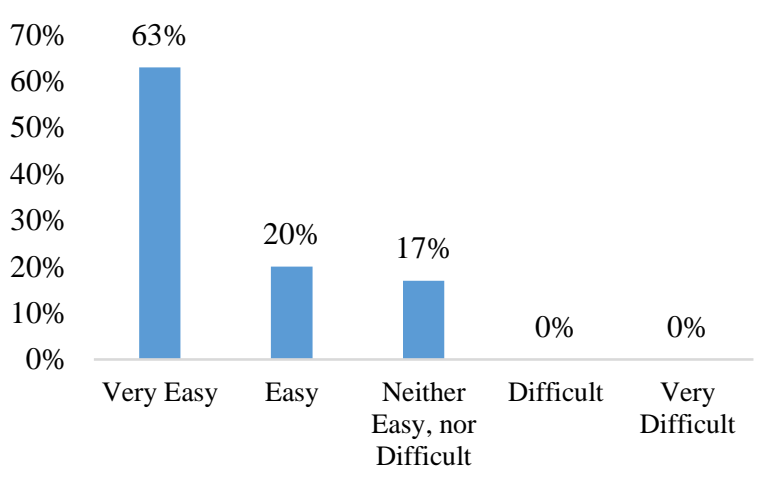

Figure 2 Complexity of access to the Planning System Source: Coordination of Strategic Planning FIME, UANL 2021

Regarding sentence number 2, $50 \%$ of those responsible consider that, with the redesign of the platform, Tactical Planning is easy to capture (Figure 3 ).

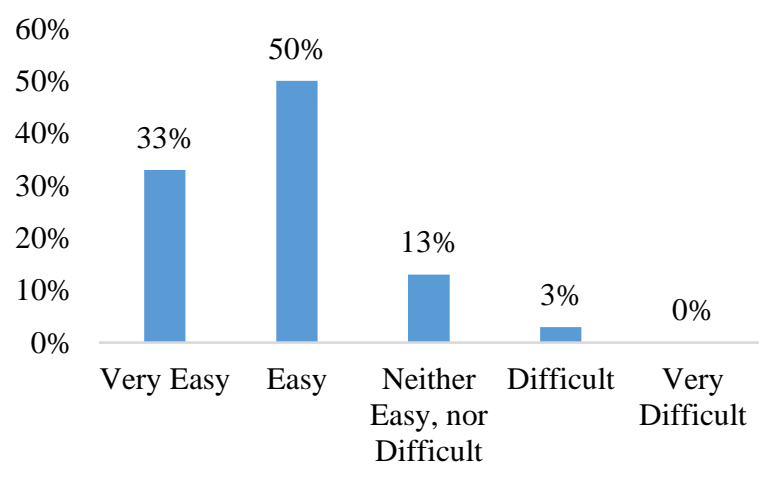

Figure 3 Complexity in Planning Capture Source: Coordination of Strategic Planning FIME, UANL 2021

Regarding the system interface, in Figure 4 we can see that $40 \%$ concluded that the redesign of the Tactical Planning presents a very easy-to-use interface, which makes it attractive for the user and easy to use.

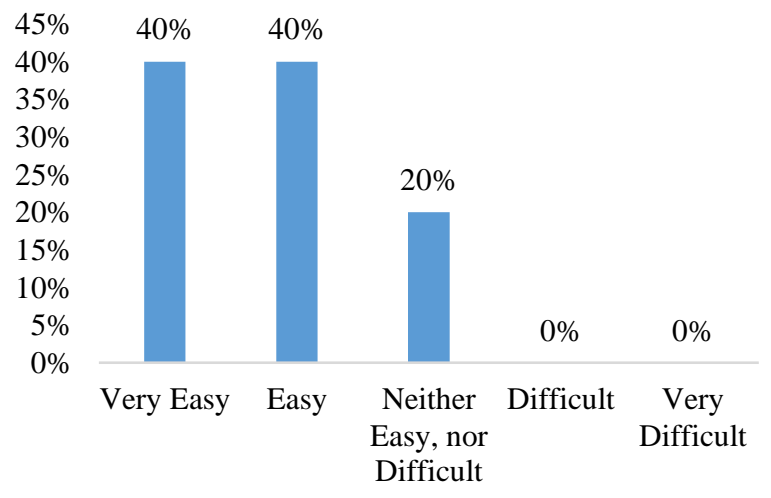

Figure 4 Complexity of the System Interface Source: Coordination of Strategic Planning 
Achieving easy navigation for the user was one of the most important points at the time of redesigning the Planning System. Regarding this, after capturing the corresponding planning, $37 \%$ of those responsible have documented that they consider that the site has easy and simple navigation, so it is not difficult for them to move from one point to another for the elaboration of the Planning exercise (Figure 5).

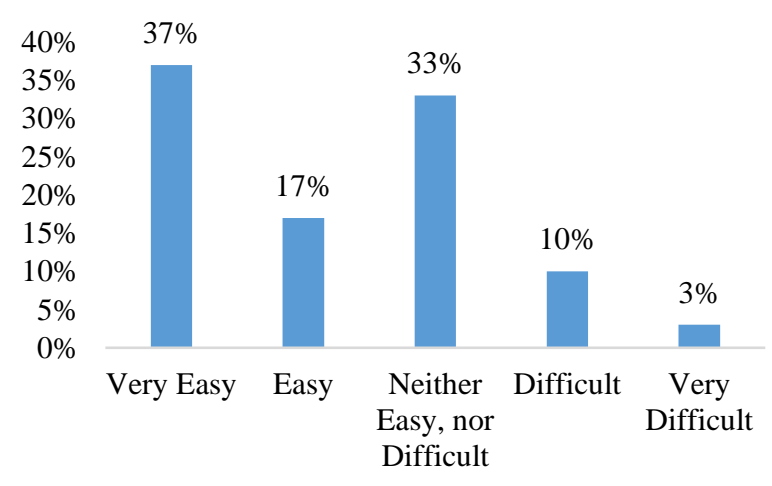

Figure 5 Complexity of Navigation in the Planning System Source: Coordination of Strategic Planning

Regarding the organization of the categories within the Tactical Planning, 47\% of the people interviewed agreed that the way in which the planning was organized facilitates the capture of the aforementioned exercise. While only $17 \%$ consider that it is very difficult for them (Figure 6).

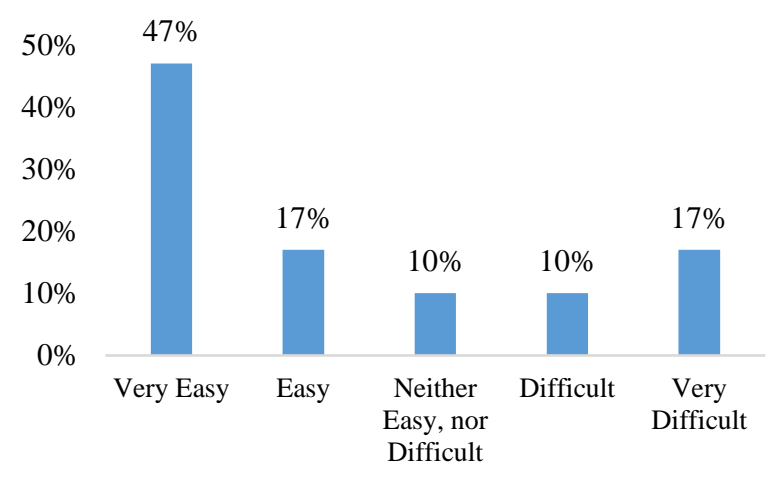

Figure 6 Capture complexity due to the organization of Tactical Planning

Source: Coordination of Strategic Planning

The second part consisted of five open questions whose purpose was to know the opinion on the redesign of the Tactical Planning, Likewise, with these questions it was intended to detect the areas for improvement that could help to provide a better service for its users. In addition to complementing the previous Likert scale by providing the option for users to elaborate on their comments regarding the redesign of the platform.
The first question focused on contextualizing users about their knowledge about what Tactical Planning is for them. 93\% of the responses were similar, so we can summarize that, for users, Tactical Planning is a work tool that helps them meet the established objectives through the proposal of strategies and necessary resources.

Regarding the second question, $90 \%$ of the users agreed that the redesign of the Planning facilitated the capture because the Planning System has a user-friendly interface, its access is easy and simple. In addition, they mentioned that the organization of the sections makes the capture simple and intuitive.

Likewise, regarding the third question, those responsible concluded that the management of the platform does not have any complications since they consider that navigation through the site is extremely easy and intuitive. In addition, they added that the instructions in each section help to a great extent to carry out a correct handling of the site in question. The fourth question addressed the relationship of Tactical Planning with Priority Programs and Quality Objectives stipulated in the Institution's Development Plan. Regarding this, users agreed that, thanks to this redesign, the alignment of actions and strategies with these points was much easier to do compared to the previous format.

Finally, among the areas of opportunity consulted in question five, it was identified that $80 \%$ of the cases made recommendations regarding the physical aspect of the site, such as the printing format of the Tactical Planning, in which we are currently working with in order to provide a better user experience.

\section{Conclusions}

In conclusion, Tactical Planning is a tool that helps us ensure that the use of resources is adjusted to the needs of the area in order to achieve the objectives of the Educational Program. This document shows that, among the benefits of the redesign of the Tactical Planning system, there is a more user-friendly interface for users, however, it invites us to continue documenting your experience to find areas of opportunity for it. 
As well as it is also recommended to carry out a constant update regarding what is declared in the Priority Programs and Guiding Axes of the Development Plans of the UANL and the FIME, as well as the reforms that the Government Accounting may present.

\section{References}

Cárdenas, et al (2017) ¿Existe Relación entre la Gestión Administrativa y la Innovación Educativa? Un Estudio de Caso en Educación Superior. Revista Iberoamericana sobre Calidad, Eficacia y Cambio en Educación, 2017, 15(1), 19-35. doi:10.15366/reice2017.15.1.002

Cárdenas, C. y Santos, O. (2021). La gestión de los directivos y la calidad del servicio educativo del colegio San Antonio Marianistas, Bellavista, Región Callao. Journal of the Academy, 4, 6389. https://doi.org/10.47058/j

Chiavenato, I. (2017). Planeación estratégica (3.a ed.). Editorial McGraw-Hill.

Clímaco Cañarte, J. (2012). Antecedentes del proceso de planeación estratégica como fundamentos para el logro de un desarrollo endógeno sustentable desde la universidad. Humanidades Médicas, 12(3), 464-486. Recuperado de http://scielo.sld.cu/scielo.php?script=sci_arttext \&pid $=$ S1727

$81202012000300008 \& \operatorname{lng}=e s \& \operatorname{lng}=e s$

Cruz Cárdenas, C. A., \& Santos Jiménez, O. C. (2021). La gestión de los directivos y la calidad del servicio educativo del colegio San Antonio Marianistas, Bellavista, Región Callao. Journal of the Academy, 4, 63-89. https://doi.org/10.47058/joa4.5

Fournier-Bonilla, S. D., Watson, K. L., \& Malavé, C. (2000). Quality Planning in Engineering Education: Analysis of Alternative Implementations of a New First-Year Curriculum at Texas A\&M University. Journal of Engineering Education, 89(3), 315-322. https://doi.org/10.1002/j.2168-

9830.2000.tb00531.x
Hernández - Sampieri, R., Collado, C. F., Lucio, P. B., Valencia, S. M., \& Torres, C. P. M. (2014). Metodología de la investigación (6.a ed.). McGraw-Hill Education.

Hernández - Sampieri, R., \& Mendoza Torres, C. P. (2018). Metodología de la Investigación: Las rutas cuantitativa, cualitativa y mixta (1a ed.). McGraw-Hill.

Martínez Corona, J. I., Aragón Paulin, R., \& Gil Nuño, B. L. (2016). Convergencia: Acreditación, Certificación y Planeación Estratégica para el Desarrollo de una Institución de Educación Superior. ANFEI, 4, 1-5. Https://www.Anfei.Mx/Revista/Index.Php/Revi sta/Article/View/227

Hernández Mendoza F. (2016). Planeación $\begin{array}{llll}\text { Táctica } & \text { y } & \text { Operativa. } & \text { 248.48.64. }\end{array}$ http://132.248.48.64/repositorio/moodle/pluginf ile.php/1297/mod_resource/content/1/contenido/ index.html

Ramírez, A., López, A., López, C., Vallejos, D., Osagueda, D., \& Vega, E. et al. (2019). El Arte de Planificar (1st ed.). México: FUPECG.

Raygoza, et al (2016) Fortalezas y Debilidades del programa educativo Ingeniero en Gestión Empresarial, Revista ANFEI Digital Año 2 Núm. 4 Enero-Junio 2016 recuperado Febrero 152021

Universidad Autónoma de Nuevo León. (2019). UANL: Plan de Desarrollo 2019 - 2030. México. Recuperado de: https://www.uanl.mx/universidad-autonoma-denuevo-leon/ Febrero 152021

Universidad Veracruzana Criterios generales para la elaboración del Plan General de Desarrollo (PI-PP-OT-01). (2021). Recuperado de: https://www.uv.mx/orgmet/files/2021/05/pipp-ot-01.pdf 